\title{
A Comparison of Problems Faced by Mathematics Teacher - Educators in Developing and Developed Countries -- A Case Study of Nepal and England
}

\section{ABSTENTCT}

Hari Prasad Ko1rala

There is still a shortage of qualified mathematics teachers in schools in developed and developing countries. It may be because of the problems facing mathematics teachers in schools and the problems facing mathematics teacher-educators in colleges of education who are responsible in producing qualified mathematics teachers. Mathematics teachers and educators are more concerned about the former and the latter is usually neglected. This article tries to trace out the problems facing mathematics teacher-educators in both developing and developed countries on the basis of a study carried out in Nepal and a simflar study in England. 15 out of 16 and 135 out of 247 mathematical educators in Nepal and England respectively took part in these studies. It was found that lack of books and fournals, teaching facilities and aids and negligible grants for research or personal studies are the main problems for mathematics teacher-educators both in Nepal and England. However it was seen that the problems faced by mathematical educators in Nepal were more serious than those of England.

\section{INTRODUCTION}

Lack of application of mathematics teaching in school level to real life situation has been a serious problem in many countries of the world. Even the most developed country like the USA has not got rid of this problem (Sonnabend, 1985). Consequently a large number of high school graduates and adults cannot use in daily life the mathematics they have learned in school. Nor can they use it in thelr Jobs (Usiskin, 1985; The Cockcroft Report, 1982). Furthermore the teaching of mathematics in school has not still been satisfactory. For example, the report of a survey carried out by the Department of Education and Sclence (DES) in England asserted that the teaching of mathematics in many secondary schools was teachers dominated and pupils were not encouraged in creative thinking and enquiry (DES, 1979). The samething was also found in Nepal, but in addition no instructional materlals other than blackboard, chalk and student geometry box (while doing construction works) were used in mathematics teaching in Nepal (Shrestha et al., 1985).

Teachers are very important factor in overcoining the above mentioned problems. It is the teacher who can influence the attitude to mathematics of his pupils. And only by the hard work of teachers a mathematics curriculum can be successfuliy implemented. If the teachers are

Koirala is a Lecturer, Mathematios Department, Engineering Campus, xmachaur, Pokhara, Nepal. 
not well-qualified the successful implementation of a mathematics curriculum is unilkely. So it can be argued that one of the causes of these problems in the teaching of mathematics in school is the lack of wellqualified teachers.

The shortage of well-qualified teachers is a tremendous problems all over the world. A survey was carried out in 24 secondary schools in different parts of Nepal--most of the schools being in the capital city, Kathmandu. It was found that only one-third of the total teachers in those schools were professionally trained (Shrestha et al., op. cit.). A similar situation of the shortage of qualified mathematics teachers in Indonesia, Nigeria and West Africa is discussed by Sowdijarto and Khodir, Fakuade and Ale (Sowdijarto and Khodir, 1980; Fakuade, 1979; Ale, 1981). This problem was even realised in England and Wales. According to a survey of secondary staffing $38 \%$ of mathematics teachers in secondary schools in England and Wales were 11l-qualifled (The Cockcroft Report, op. cft.). The similar discussion of teacher shortages in England and Wales can be seen in the report of the Royal Society and a memorandum submitted to the James Committee by the National Union of Students (NUS).

The shortage of wel1-qualified mathematics teachers in many countries is linked with colleges of education or similar institutions who offer courses for pre-service and/or in-service teachers. Hence it raises the question of efficiency of teacher training institutions in those countries. In some countries mathematics teacher-educators are facing simflar problems as those of school teachers. For example, in Nepal the campuses under the Institute of Education lacked qualified staff and resource materials such as assigned texts, detailed course contents, NESP* school materials and reference works (Shrestha, 1976). In another study in Nepal, Shrestha (1977) observed that the campuses under the Institute of Education lacked teaching aids and materials. And no teaching alds except blackboards were used in the classroom. Furthermore lecture method was the dominant method of instruction. Thus it is more 1ikely that the teachers prepared by these campuses will follow the same method of instruction which they have experienced from their lecturers. In the case of England and Wales the problems appear a bit different. According to some reports published the training courses offered by colleges of education in England and Wales lacked relevance to the job of teachers. They also reported that some of the teacher training courses were felt Inadequate (The James Report, 1972; NUS, 1971; Draper, 1974; Bassey, 1980).

In the light of the above problems in teacher training institutions it is worth looking at the conditions of mathematics teacher-educators working in those institutes. Otte (1979) argued for an opportunity of self-study and research works for teacher educators so that they can be up-to-date and acquire necessary qualifications of current trends. He also indicated that these types of opportunities are very less for teacher educators. Is the situation still not improved? One of the focusses of these studies was to find the answer of this question with respect to mathematics teacher-educators. Besides this, curriculum and textbooks, teaching facilities and alds, students' background and some other personal matters of lecturers themselves such as promotional prospects, salary to maintain their family can be the major obstacles in overcoming the

*NESP Is an abbreviation for National Education system Plan. 
problems seen in colleges of education. This article is an attempt to trace out the problems facing mathematies teacher-educators in Nepal and England with respect to the above mentioned areas.

\section{METHOD}

The Nepalese study was carried out in the beginning of 1985 with a view to identifying problems facing mathematics educators in Nepal in the implementation of B.Ed. level mathematics curriculum. A questionnaire was constructed and distributed in person to all sixteen concerned mathematics educators in all four campuses in Nepal. Fifteen responses were made and analyzed by calculating means.

The English study started by looking at the previously used questionnaire In Nepal by Kolrala (1985). Since the purpose of the English study was a bit different and workfing way of the English teacher training system was also different, a new questionnaire was made for use in England. The questionnalre was malled to all 247 lecturers involved in every mathematics education programme (primary and secondary teacher training programme) in 75 colleges of education and polytechnics in England in February 1986 . 135 responses $(54.7 \%)$ were obtained. The data thus obtained through the questionnaire were processed on the university computer and analyzed by calculating percentage or one or more of the following statistical measures--mean values, standard deviations and correlation coefficients.

\section{The Questionnalres}

The Nepalese questionnaire consisted of 62 question 1tems in 3point scale (Yes; Indifference, NO) related, to the objectives, contents, teaching methods, instructional aids and evaluation devices in order to collect information regarding the problems faced by mathematics educators.
For example.

"The objectives are suitable to meet the needs of the students as well as national needs."

"The evaluation techniques are suggested In each course."

"The textbooks recommended are available to students/teachers through purchase or I1brary use."

In addition some open questions were also asked which helped to seek out some more problems of mathematics educators.

The English questionnaire comprised question items related to curriculum issues, textbooks, teaching facilities and aids, students' background to follow lectures and the personal matters of lecturers themselves. The questionnaire contained the items such as lecturers' involvement in designing the course; statements and sultability of aims and objectives, teaching practice, teaching methods, teaching aids and methods of assessing students' performance, avallability and relevance of college and school textbooks and national and international journals related to mathematical education, avallability of mathematics rooms and 
laboratories, avallability and adequacy of certain'materials such as micro-computer, video-recorder, overhead projector, mathematical models and charts etc, and the personal matters of lecturers themselves such as their load of teaching, promotional prospects, salary to maintain family and professional satisfaction. For instance some of the items are:

"I am involved in designing the course I teach."

"The objectives are suitable to meet the needs of the students."

"The syllabus suggests methods of assessing the students' performance."

"All the college textbooks recommended in the syllabus are available in the library."

In the tems related to curriculum 1ssues, the respondents were asked to $t i c k(V)$ an appropriate column of a five-polnt Likert scale ranging from Strongly disagree to Strongly agree. Other 1 tems were expressed in Yes, No column or a 5 or 7-point scale. For example,

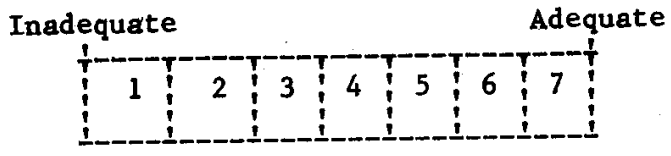

At the end of each section of the questionnaires (both the Nepalese and English) the respondents were requested to comment on the problems not covered by the items of the questionnalre.

The items expressed in different scale (3- or 5- or 7-point scale) were awarded a score of 1 to 3 or 1 to 5 or 1 to 7 respectively in the analysis of data. The comments given by the lecturers were analyzed with the help of tabulation. The results of the analysis are discussed in the succeeding paragraphs.

\section{RESULTS AND DISCUSSION}

Curriculum/Syllabus: Almost all the lecturers (128 out of 133) in England were Involved in designing the course they taught. However this involvement. was not necessarily through the meeting of mathematics department staff in some of the colleges as 17 lecturers out of 130 indicated that there were no frequent meetings of mathematics department dicated to decide upon course matters. Some of the lecturers commented that there were informal meetings rather than formal. Anyway there is enough evidence to say that lecturers' involvement in designing the course is sufficient in England. If the situation of lecturers' involvement in designing the course is turned back to Nepal it is rather disappointing. Usually the syllabi or curricula are framed by a subject comittee which consists of members mostly from the campuses in the Kathmandu Valley. Even more embarrassing is that the meetings of the subject committee are very very few. So the mathematics department staff of a particular campus can hard1y do anything agalnst or for the 
syllab1. Althou: a in the case of Englend there are written statements of the alms and objectives of the courses and they seem suitable to meet the national needs and the students' needs it is very difficult to achieve those aims and objectives in the real term. There are various reasons for this difficulty. One of the reasons is because of the difficulty to finish the courses on time especially the content courses in mathematics. And as it is sald earlier the lecturers cannot do anything against the courses (even some of them are quite long) because the examinations are centralised. Moreover if there are any problems durfog the teaching of any courses the lecturer concerned cannot solve the problems and may need argued that the lecturers for the solution. In conclusion, it can be argued that the lecturers' Involvement in designing the courses in Nepal exists at the present.

Teaching practice of students in colleges of education in England is heavily emphasised as an integral part of the syllabus (Mean value 4.076 in a 5-point scale). In England most of the colleges of education tor's suching practice perfod of 12 weeks. However to the investigatice studentse some lecturers found it difficult to visit teaching pracin colleges and visited by them practice frequently (at it is essential to visit students on teaching provision for Nevertheless the Nepalese mathematicsators to overcome these problems. Nevertheless the Nepalese mathematics educators to overcome these probtice of the english mathematics educators regarding the teaching practice of the students. In Nepal the teaching practice perlod usually to visit students on . And lecturers were facing every type of problems led, a large number teaching practice such as long distance to be travelin colleges.

Not only do the mathematics educators in Nepal have problems regarding teaching practice of the students their colleges also have the problems in selecting cooperative schools. Usually many schools in Nepal schools do not want to students on teaching practice. More than that some students on teaching practice at all. This raises the question of efficiency of teaching practice programme conducted by the campuses under the Institute of Education in Nepal. So, without doubt, teaching practice programe in Nepal should be evaluated on a wide scale and a better provision should be made to improve it.

Another interesting result about teaching practice in England was a moderate correlation coefficient $(.4615)$ between the emphasis given on teaching practice and the provision for students to tackle mixed abithat students can be trained somewhat in tacking mixed ability classes during their teaching practice periods. ability class in Nepal.

In the question 1tems related to methods of teaching, teaching aids and assessing the tudents' performance $65.9 \%$ of the English lecturers stated that the method of teaching certain topics was not suggested in the syllabus. However a great proportion of the lecturers 
(70.4\%) claimed that certain teaching aids to be used by lecturers were suggested in the syllabus. Almost the same proportion of the lecturers (69.6\%) expressed that their syllabus suggested methods of assessing the students' performance. The situation in Nepal was more or less similar to those of England. Nonetheless, since most of the mathematics educators in Nepal are not involved in designing the course they taught they can be in serious problem about methods of teaching, teaching aids to be used in the classroom and methods of assessing students' performance. This idea also supports that lecturers' involvement in designing the course should be high.

Textbooks: This section sought out the avallability of college textbooks (books about the pedagogical and theoretical aspect of mathematics), school textbooks (various schemes of textbooks used in different types of schools), national and international journals related to mathematical education for both lecturers' and students' use. According to $80 \%$ of the 135 lecturers in England college textbooks are recommended in the syllabus. However only $58.5 \%$ stated that school textbooks are also recommended in. the syllabus. Some lecturers commented that they themselves recommend books for students and it is, not, necessary to recoumend books in the syllabus. But only about $32 \%$ of the lecturers got college- and school-textbooks frotn thelr colleges. However $79.3 \%$ and $62.2 \%$ of the 135 lecturers claimed that all the college- and school-textbooks recommended in the syliabus are avallable in the library. An encouraging result, perhaps, is the availability of important national journals of mathematical education to $31.9 \%$ of the lecturers and the availability of important international journals of mathematical education to $15.6 \%$ of the lecturers for their personal use. Also all the important fournals (both the naticnal and international) related to mathematical education were avallable in the college 1ibrary according to $73.3 \%$ of the lecturers. Still there is the facility of interlibrary loans to both lectuxers and students in Britain. So, on the whole, it can be argued that the degree of the problem of the unavallability of books and fournals in most colleges of education in England is not serfous. But in Nepal the problem of unavallability of books and journals has been a serious problem. In Nepal usually the books in mathematics education in campus level are written in English and published abroad. So they are usually very expensive and the campuses cannot buy them. Many campuses even do not have money to purchase the adequate coples of school textbooks. Iittle wonder there is not a single national journal in mathematics education in Nepal.. And international journals are not available. Thus many mathematical educators in Nepal cannot get the opportunity to know the new development in their field. In fact this is the most serious problem for a professional person. So efforts must be made to start a national fournal of mathematical education and finance must be searched to purchase some important international journals of mathematical education at least in the central library in Kathmandu.

Teaching Facilities and Aids: Teaching facilities and aids play an

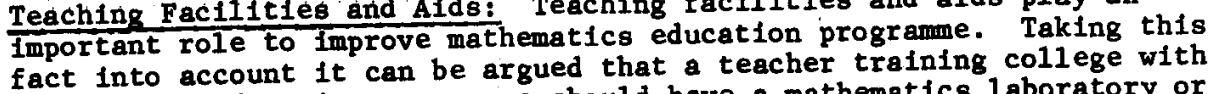
mathematics education programe should have a mathematics laboratory or a mathematics resource centre. In a question about the existence of a 
mathematics laboratory or a mathematics resource centre, most lecturers (85\%) In England recorded that their college of education have at least a mathematics laboratory, a mathematics resource centre or a mathematics room. The rest of the lecturers with the exception of one expressed that they have general audio-visual aids department, general resource centre or teaching practice resources laboratory where the materials are aval1able. Thus there seems not to have any problems with the absence of a mathematics laboratory or a mathematics regource centre in colleges of education in England. However to the investigator's surprise, about $40 \%$ of the lecturers indicated that they had no sufficient lecture rooms with enough furniture and even the mathematics laboratories or the mathematics resource centres were not of reasonable size to work with students. Even more surprising, perhaps, is the lack of opportunity given to students to use the mathematics laboratory freely. Only $37.8 \%$ of the lecturers recorded such opportunity. More than that only $12.6 \%$ deemed that a lecturer can be avallable in the mathematics laboratory if a student needs help. Thus the situation in colleges of education in England with regard to the use of the mathematics laboratories by students 18 not encouraging. Nevertheless, there is one encouraging result as well. That is, according to $54.8 \%$ of the lecturers their students can borrow essential materials from the mathematics laboratories during their teaching practice. If we turn back to Nepal in the above matters the situation is more disappointing. Although in most campuses under the IOE in Nepal have a designated mathematics laboratory, their sizes are not reasonable to work with students. And because of the lack of rooms in many campuses these mathematics laboratories are also assigned as lecture roous, so the students cannot $g \circ$ and work in the laboratories. Besides, the facilities of loans (books and materials)-from mathematics laboratories to students in Nepal is almost Impossible.

The next concern of the investigation was to measure the avallability and adequacy of materials such as video-recorder, micro-computer, overhead profector, film projector, calculator, duplicator, photocopler, mathematical models, mathematical charts, cardboard, plywood and tools and college and school books in the mathematics laboratory. Well over $80 \%$ of the lecturers asserted that the materials 11ke micro-computer, overhead projector, calculator, mathematical models, mathematical charts and school books were avallable in the mathematics laboratorles in colleges of education in England. It is certainly a good indication that even the materials like photocopler and some international journals of mathematical education were avallable in the mathematics laboratories of about $30 \%$ lecturers' college. It is necessary to mention here that many lecturers commented on the avallability of these 1tems and made it clear that the materials 1.1ke video-recorder, micro-computer, overhead profector, film profector, calculator, duplicator, photocopier, mathematical models and mathematical charts could be booked for classrooms use (1f not avallable in the mathematics laboratory) through a general or central resources. Besides these, books and journals could be found in the 11brary. Another encouraging result is about the adequacy of materials in the mathematics laboratories. Most of the lecturers were quite satisfied with the adequacy of the above mentioned materials in their mathematics laboratories. On the basis of these information obtained from the lecturers it can be concluded that most colleges of education 
in England have adequate materlals and only a few have some problems with the adequacy of materials. On the other hand, the only materials available in the mathematics laboratories of the campuses under the IOE are some mathematica nodels and charts, cardboard, plywood and tools and some college and school textbooks. As Indicated by the Nepalese lecturers even these meterials are not adequate. The avallability of the materlals 11ke video-recorder, micro-computer, overhead projector, film projector, duplicator, photocopler in each campus under the IOE in Nepal sounds like a nightmare at the present. Even the most common materlals like calculator is not available for students' in Nepal. Thus the materials avallable to the Nepalese lecturers are quite inadequate in comparison to the English lecturers. In order to Improve the mathematics education programe in Nepal finances must be found for keeping teaching materials and alds in the mathematics laboratories and a more emphasis should be given to produce and use local teaching materials.

Students' Background: It is generally agreed fact that pupils in school differ in the ablitty of learning of mathenatics due to various backgrounds such as intelifgence, sex, maturity, socio-economic status. It is almost the same for students in a teacher training college. Besides that the ability of students in a teacher training college may have been affected by their school education and their experience of teaching in a school (if they are in-service students). And students in a teacher training college may have been planning to teach in different types of schools. Due to all these differences in students' background the same lecture may not fit for all. students. The James Report in England was concerned about this fact a long ago. However the situation is still not positive towards this 11ne. Out of 135 lecturers a little more than 80\% said that their students in colleges of education come from various school backgrounds and they have to train them to fit for different types of schools. The experience of in-service teachers is not the same as one another according to $77 \%$ of the lecturers and according to $14.8 \%$ inservice and pre-service teachers are mixed in some of their classes. Surprisingly, in spite of all the above unfavourable situations, the majority of the lecturers in England claimed that they had no problems because of a weak students' background to follow their lectures (Mean value 5.0 in a 7-point scale) and because of students' negative attitude towards the teaching and learning of mathemat1cs (Mean value 3.803 in a 5-point scale).

In Nepal students in campuses under the IOE come from schools in urban and rural aceas, especially more from rural areas. Since the standard of schools in urban and rural areas are different it can be said that students in those campuses have different background of school education. And in-service and pre-service. teachers are mixed in more of the classes in those campuses. However, unlike English lecturers some of the Nepalese lecturers strongly Indicated that they had problems because of a weak students' background to follow lectures and students negative attitude towards the teaching and learning of mathematics (especially in the content courses of mathematics). This might be because of less attraction towards teaching job in comparison to other jobs in government service. Nevertheless this is a problem to which Repalese mathematics educators should give attention. 
Personal Problems of Lecturers: The personal matters of lecturers such as load of teaching, grants recelved for research or personal studies, promotional prospects, salary to maintain family, professional satisfaction are important elements to Increase lecturers teaching efficiency. Unless the above matters are favourable a lecturer cannot be expected to do his best to the institute even if there are good curriculum and textbooks and enough teaching facilities and alds.

Perhaps the most serlous problem for lecturers in England is the high teaching load given to them. The mean value on this item 18 well over the mid value (Mean 5.47 in a 7-point scale) of the scale and not a single lecturer ticked 1 (the lowest value of the scale) on this item. A similar degree of problems faced by many lecturers in England is that they hardly recelve grants for research or personal studies. The grants received by lecturers for research or personal studies have always been low. The NUS (1971) in the UK produced an evidence that the money spent on educational research was less in comparison to other fields such as agriculture, science, medical and belleved that the total educational research budget needed to be five times greater than the present one. Although this investigation has no evidence about how much more money should be spent on educational research in England it has sufficient evidence to say that more moneps should be spent on $i t$.

The mean value on the promotional prospects of lecturers is clearly under the mid-value (Mean yalue 2.57 in a 7-point scale) of the scale. This provides evidence that the promotional prospects for the majority of the lecturers in England are not good enough $56.3 \%$ of the lecturers Indicated that their promotional prospects were bad and a further $34.1 \%$ had no strong opinion. More than that some lecturers (39 out of 135) considered their salary as not enough in maintaining their family.

Thus many lecturers in England are facing serious problems at personal level, the high load of teaching and the lack of funds being the mafor ones. However in spite of so many personal problems, most lecturers in England are professionally satisfied. This is the most encouraging result. Although the personal matters of lecturers were not asked in the previously used questionnalre in Nepal, everyday working in teacher training has given the investigator sufficient experience to forecast that the results would be similar to those of England. Knowing the Nepalese scene it came as a surprise to the investigator that lecturers in a developed country like England have many of the same problems.

\section{CONCLUSION}

Mathematics teacher education programme in Nepal is disturbed by so many factors such as lack of lecturers involvement in curriculum planning, lack of efficiency to conduct teaching practice of the students, lack of books and journals and teaching facilities and aids, a weak students' background towards the subject matter and a huge number of personal problems to lecturers. Most of the above problems are the products of financlal difficulty. However some of them such as only a ittle lecturers' 'Involvement in designing the courses is responsibie to some extent to the inefficient academic management as well. It would 
be logical to say that mathematics education in Nepal is essentlally suffering from the above problems faced by mathematics teacher educators in the teacher training institutions.

Mathematics teacher education in England seems to have less problems than those of Nepal. However England also has not got rid of all spots of problems. The personal problems to mathematics teacher educators in Nepal and England are similar. Nevertheless financial problems are more acute in Nepal. In spite of the above problems Nepalese teacher training can learn something from the English system. First Nepal should try to encourage more lecturers' involvement in curriculum planning and second give more emphasis on teaching practice of the students so that they can be more in touch with classroom reality. More finances should be searched out to solve the problems of books, journals, teaching facilities and aids. Emphasis should be given in constructing teaching materials locally rather than buying expensive teaching aids. Seminars/ workshops of lecturers should be conducted time to time (at least once a year) and a new way of teaching and constructing materials should be discussed.

\section{References Cited}

Ale, S.0., "Difficulties Facing Mathematics Teachers in Developing Countries--A Case Study of Nigeria", Educational Studies in Mathemat1cs, XII, 1981 .

Bassey, M., "131 Primary School Teachers' Opinions About Their College Training", Trent Polytechnic', 1980.

Department of Education and Science, Aspects of Secondary Education in England: A Survey by H.M. Inspectors of Schools, London: HMSO, 1979.

Draper, A.C., "A Survey of Heads of School Mathematics Departments, Ratings of New Mathematics Teachers"; Mathematical Education for Teaching, 1,3 (May 1974).

Fakuade, R.A., "An Irvestigation of the Problems Involved in the TeachIng and Learning of Mathematics in Some Nigerian Secondary Grammar Schools in Oyo, Ogun and Ondo States", A Ph.D. Thesis, University of Wales, 1979.

Koirala, H.P., "Problems Faced by Mathematics Teacher Educators in the Implementation of Mathematics Curriculum for Prospective Secondary School Teachers", A Field Study, IOE, Tribhuvan University, Nepal, 1985 .

Otte, M., "The Educational and Professional Life of Mathematics Teachers", New Trends in Mathematics Teaching, Vo1. 4, Paris: UNESCO, 1979.

Shrestha, M.M., "An Evaluative Study of the Ongoing Mathematics Program for Prospective Primary School Teachers in Nepal", A Ph.D. Thesis, The Pennsylvania State University, USA, 1977. 
Shrestha, M.M., Koirala, H.P. and Mcllhenny, A.J., Teaching Mathematics to Large Classes in Nepal--A Study with Pract lcal Suggestions, Kathmandu: IOE/UMN, 1985.

Shrestha, S.K., "Report on Teacher Education in Mathematics", Tribhuvan University, IOE, Kathmandu, 1976.

Sowdijarto, R.I. and Khodir, A., "The Indonesian Modular Instructional System for School Mathematics". Morris,-R. (ed.), Studies in Mathematics Education, Vo1. 1, Paris: UNESCO, 1980.

Sonnabend, T., "Noncareer Mathematics: The Mathematics We All Need", The Secondary School Mathematics Curriculum: 1985 Yearbook of the National Counc1l of Teachers of Mathemat 1CS, USA: NCTM, 1985.

The Cockcroft Report, Mathematics Counts: Report of the Committee of Inquiry into the Teaching of Mathematics in Schools, London: HMSO, 1982 .

The James Report, Teacher Education and Training, London: HMSO, 1972.

The National Union of Students (NUS), The Education and Training of Teachers: Perspectives for Change, London: NUS, 1971.

Usiskin, Z., "We Need Another Revolution in Secondary School Mathematics", The Secondary School Mathemat1cs Curriculum: 1985 Yearbook of the NCTM, USA: NCTM, 1985. 